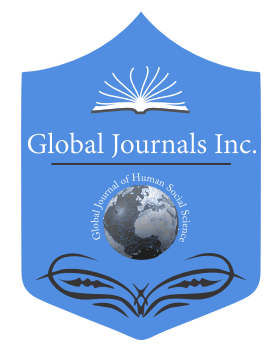

\title{
Research Subjects about the Comparison of British and Japanese Scholarship of Islam
}

By Alimu Tuoheti

Tohoku Univesiry

Abstract- All around the world, how we interpret the Islamic world objectively and accurately is an important topic for concerned scholars all over the world. Britain has a history of Islamic Studies for more than 400 years, and the current standard and research paradigm of Islamic Studies in the UK deserves our attention. It is of great practical significance for us to thoroughly and systematically understand the contemporary Islamic world in this special historical stage of great turbulence, great differentiation, and great change, and then comprehensively grasp the regional issues of Islam and build a discourse system of Islamic research with modern characteristics. In the past 30 years, Japanese academic circles have not been able to keep abreast of the development of Islamic Studies in the UK, let alone go deep into the frontier field of cultural communication. Based on this, through literature analysis and field visits, this Project intends to overview of the current situation of Islamic Studies in Britain and Japan, focusing on the two main paradigms of its cultural studies, and then to explore the how these academic efforts can benefit and impact the discourse construction of Islamic Studies in Japan and UK.

Keywords: islam british japanese comparison research subjects.

GJHSS-A Classification: FOR Code: 330205

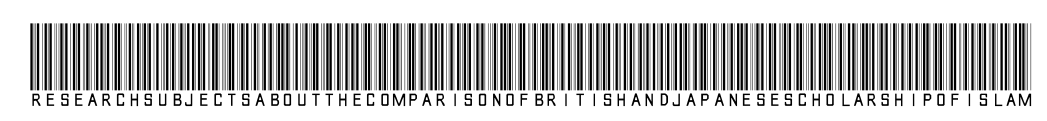

Strictly as per the compliance and regulations of:

(C) 2021. Alimu Tuoheti. This is a research/review paper, distributed under the terms of the Creative Commons AttributionNoncommercial 3.0 Unported License http://creativecommons.org/licenses/by-nc/3.0/), permitting all non-commercial use, distribution, and reproduction in any medium, provided the original work is properly cited. 


\title{
Research Subjects about the Comparison of British and Japanese Scholarship of Islam
}

\author{
Alimu Tuoheti
}

\begin{abstract}
All around the world, how we interpret the Islamic world objectively and accurately is an important topic for concerned scholars all over the world. Britain has a history of Islamic Studies for more than 400 years, and the current standard and research paradigm of Islamic Studies in the UK deserves our attention. It is of great practical significance for us to thoroughly and systematically understand the contemporary Islamic world in this special historical stage of great turbulence, great differentiation, and great change, and then comprehensively grasp the regional issues of Islam and build a discourse system of Islamic research with modern characteristics. In the past 30 years, Japanese academic circles have not been able to keep abreast of the development of Islamic Studies in the UK, let alone go deep into the frontier field of cultural communication. Based on this, through literature analysis and field visits, this Project intends to overview of the current situation of Islamic Studies in Britain and Japan, focusing on the two main paradigms of its cultural studies, and then to explore the how these academic efforts can benefit and impact the discourse construction of Islamic Studies in Japan and UK.
\end{abstract}

The main purpose of this research is to summarize the research process and achievements of World Islam and Muslims, from the perspective of academic history in Japanese and English. This is to provide scholars with a summary of existing research, and to lay a starting point for researchers who are trying to engage in Islamic studies and other related fields. The second is to provide later scholars with the literature of Islamic studies in this period. Conversely, the far-reaching significance of this study lies in enabling scholars to fully realize that combing and summarizing the existing academic achievements is an indispensable key link in the research process, to enhance the research consciousness of academic history and establish the norms of academic research.

This research topic, especially in today's COVID era, is of great significance to understand the changes in the Islamic world.

Keywords: islam british japanese comparison research subjects.

\section{INTRODUCTION}

slamic Studies in Britain originated from the study of Middle Eastern languages as an aid to Biblical Studies. As early as 1632 and 1634 respectively, two universities, Oxford and Cambridge, set up the position of Arabic professor. Since then, driven by Britain's overseas trade and colonial expansion, as well as the influence of the European Enlightenment, the French Revolution and the subsequent two World Wars, Islamic studies has gradually expanded to the history and

Author: Tohoku Univesiry/Jaopan.e-mail: tuoheti.alimu@orinst.ox.ac.uk culture of Islamic Society (especially customs and habits), Islamic religion, Islamic literature and translation and other fields. The form of its achievements has also changed, from the independent work of British scholars to cooperation with scholars from other western countries (Such as the Encyclopedia of Islam, Cambridge History of Islam, and other key works). After four centuries of development, especially in the past 50 years, Islamic research in Britain has formed a broad and profound research system. With the independence of the Islamic countries after World War II, the Middle East and Islamic studies began to flourish in the UK. The focus of their research has gradually shifted from traditional history and linguistics to sociology and cultural research fields that have one step in the future. In the 1980s, mass media and new media culture research became a new emerging study in the field of cultural research. Some Middle East and Islamic researchers began to develop the research methods based on mass media and new media culture, and formed a new cross-border study of Islam from the perspective of media culture. Among the numerous research institutions, University of Oxford (including the Department of Oriental Studies, the Middle East Centre, and the affiliated Oxford Centre of Islamic Studies), the Islamic Research Centre of Cambridge University and the Islamic Research Centre of the School of Oriental and African Studies of the University of London are the most famous research centers.

1. A comparison of Japanese and British scholarship on Islam: Until the early 20th century, Japan still had not formed an academic system to study Islamic world. Therefore, Japanese scholars attached importance to the research and translation work of other European and American countries, including the UK, which then gradually built the foundation of the Japanese study. The first step was to start with the collation and translation of documents as the carrier of Islamic culture. In the late 19th century and the early 20th century, Western missionaries paid much attention to Islam, so some works of sorting out Islamic documents by foreigners represented by missionaries appeared. The earlier concerns about Islamic literature are the "Notes on Chinese Literature" (Shanghai American Presbyterian Mission press, London: Trubner \& Co, 1867) published by Alexander Wyllie, a British missionary. Under this influence, Japan began to pay attention to the 
collation and research of Islamic literature abroad. At first, there were studies of Rokuro Kuwata (桑田六郎) and Mikinosuki Ishida (石田 幹之助）. In 1918, Mikinosuki Ishida published his thesis on "the Islamic literature published in China", which was the first "Islamic Literature" catalogue introduced to Japan. As a member of the editorial board of the Christian literature society in British, Isaac Mason was also interested in Chinese Islamic studies. He published several papers in the Journal of the North China Branch of the Royal Asiatic Society (JNCBRAS) and The Muslim World, which was the most comprehensive achievement in the collection and collation of Chinese Islamic literature in this period. It is a summary catalogue, collecting 318 kinds of Chinese Islamic literature before 1920s. Most of the above documents had been translated into Japanese at that time, and Japanese scholars actively referred to and quoted them, which was also the most basic foundation for the study of Islam in Japan. With the outbreak of war in 1931, the establishment of the puppet state of Manchukuo and Japan's occupation of China, how to deal with the local Muslims in Northeast and North China became Japan's top priority, and the Japanese government began to realize the necessity and importance of studying Chinese Islam. As a result, Islamic research institutions were set up to support Japan's Islamic research financially. In Japan, the new era of Islam and the Middle East studies was initiated by the Shinji Maejima (前島 信次), Toshihiko Itdutu (井筒 俊彦) and Jihei Shimada（嶋田 襄平）. Professor Shimada (19241990) studied the methodology of Islamic history in London University. On that basis, he intended to introduce European Islamic studies to Japan. Based on these studies, the Islamic and Middle East Studies in Japan have developed steadily in both quality and quantity since the 1960s. This can be confirmed by the internal development trend of the Centre for Cultural Research in East Asia (affiliated to the Dongyang Library) in "the catalogue of Islamic Studies in the Middle East of Japan: 1868-1988", which was compiled from 1992 to 1993. In Japan, ancient research preceded the contemporary political and economic research (which started after the first oil crisis in 1973), which is an important feature of postwar academic research.

2. There are two traditions of Islamic Studies in Britain, which are interlinked with each other but have different emphases. First, the tradition focuses on the cultural mapping of the Middle East in the Western world, and studies the image of Islamic civilization in the Western world, especially in the mass media. Secondly, the tradition focuses on Islamic civilization itself and studies the internal cultural phenomena and representations of Islamic society. In the second paradigm, the British scholars of Islamic culture shift their focus from the West to the Islamic world itself, in order to minimize the interference of Western ideology and better understand the interweaving of the historical tradition of Islamic society and contemporary culture. These cutting-edge studies critically use the latest Western cultural theories, and at the same time help the audience understand the middle east society more deeply through their works.

- Because of the close ties between Britain and many other geopolitical, political and economic factors such as its colonial history in the Middle East and the current wave of immigrants, the influence of Britain on the post-colonial era in the region is still huge. This kind of influence not only comes from history, but also from the research and exploration of the Islamic world by the British academics and the media. With the rapid development of media science and technology in recent years, the West has controlled the international communication pattern by using powerful media. The power of culture is more and more manifested as the power of communication, or the contest of communication power between different cultures. The influence of cultural communication is largely determined by its content quality. To study the Islamic world from the perspective of culture, the basic and applied research of contemporary British scholars deserves the attention of the international academic community, and it also has important reference value for the construction of the discourse system of Chinese Islamic studies.

- From the perspective of research characteristics, British Islamic Studies pay close attention to British social reality, and try to solve British local social problems through the research process itself. Perhaps we can understand this kind of sober "realistic consciousness" as that in a certain sense, they pay forward-looking attention to the undercurrent of social and cultural communication before major social contradictions emerge, which can play a role in exploring, tracking, warning or resolving social contradictions and even social conflicts. A series of applied research projects, led by the Centre for Islamic Studies of Cambridge University, put Islamic groups into the British social background to investigate, and work together to build a platform for communication between British Muslims and other cultures, so as to help British Muslims integrate into the mainstream society smoothly, and then help to establish a mutual trust relationship between Britain and the whole Islamic world. These experiences are worth learning from by Japanese scholars. 
In addition to the traditional research fields such as literature, language, cultural comparison and textual research of ancient books, Japan can learn from the reality of British scholars' research topics, deeply study the practical problems in the social communication and cultural communication between Muslims and nonMuslims, neighbouring countries and even Muslims in Islamic countries, pay close attention to its communication undercurrent, and actively build a harmonious society A platform for cultural exchange of good neighbourly and friendly relations.

When Japanese scholars examine the changes and characteristics of Islamic Studies in Britain, what arouses our deep thinking is not only whether we should adopt the comprehensive research method from the Triple Perspectives of Japan, the West and the Middle East Islamic world to pay attention to the "present tense" of the Islamic world in the context of globalization, but also to deeply explore its practical problems. In order to better serve the Japanese scholars' realistic demands of interpreting the Islamic world, and more importantly, our analysis of contemporary Islamic Studies in Britain is to grasp the trend of western academic practice, "see through" the diversity of Western Perspectives (the west is not monolithic), and trigger our own in-depth thinking about Islamic culture research. On this basis, we need to further consider the enrichment and improvement of our own academic discourse system. In other words, our academic position should be Japanese; Academic vision should be international.

3. This topic is named "Islamic study," relating not only to the study of Islamic religion but also to Islamic history, philosophy, politics, society, and culture. The study of World Islam and Muslims is divided into four parts: before 1900, 1900-1945, 1945-2000, and 2000-2020. Saliently, in each period, different research methods are used for World Muslims. Therefore, the author tries to make a systematic analysis of the research trend in each period and stage according to a more flexible method in the subject. This paper mainly deals with the literature, academic papers, research reports, and so on.

1) The studies of World Islam by Japanese and British Academic Society. These include: field research, literature research, translation research, folk research, etc. The author has collected all the works and related materials of the research object as effectively as possible, classified and summarized them, read and understood each word and sentence, and then analyses and synthesized them. This is an important reason for the author to choose this topic, and it is also the first rule for the writing of this topic. Because most of the works and thoughts of these people are unfamiliar to domestic academic circles, to avoid misunderstanding, we strive to use more Primary historical sources.
Primary sources will be used as much as possible. All quotations will be classified according to their understanding.

2) The study of World Islam and Muslim issues in Japanese and British is accompanied by the complex historical evolution of the world at large, including China. It can also be said that many complex factors relate to different times and backgrounds in Islamic studies and achievements. The author believes that we should not ignore the political background of the research results, but should also consider the characteristics of these studies as academic research, which relate little to politics, specifically, we should analyze and comment from an academic perspective. Therefore, in this paper, the author analyses the research and achievements related to politics and academic perspectives and comments based on their historical significance. Indeed, this topic also criticizes materials. The criterion of criticism is whether the thought itself is logical, and then whether the theory is consistent with historical facts.

According to Project's current situation: Rather than develop new ideas for the discourse on the subject, we have strived to comprehensively overview the characteristics of the Japan and UK academic community's study of Islam through the comprehensive collection, collation, and analysis of data.

Comparative Analysis: Intercultural communication is a branch of communication, which is closely related to communication and culture. At present, the definition of its attributes has been relatively clear. Through the comparative analysis of the concepts of cross-cultural communication, communication and culture, this paper would further explain the uniqueness of cross-cultural communication. Through the guidance of this theory, this study would further analyze the communication methods and communication skills of Japan and UK academic circles in the process of Islamic cultural communication. Then, it would summarize the increasingly close relationships between countries in the contemporary world, in the increasingly diversified cultural exchange and communication atmosphere, so that can we better carry out more effective cross-cultural exchange and communication with other countries.

Interdisciplinary Analysis: To complete a better job of this research, this paper comprehensively uses the knowledge of communication, sociology, history, and other aspects to analyses the communication process, communication effect, and merits of the history of crosscultural communication of Japan and UK scholars in this historical period from the perspective of a different discipline, to achieve the purpose of research.

4. The traditional research fields such as literature, language, cultural comparison and textual research 
of ancient books: Japan can learn from the reality of British scholars' research topics, deeply study the practical problems in the social communication and cultural communication between Muslims and nonMuslims, neighboring countries and even Muslims in Islamic countries, pay close attention to its communication subtexts, and actively build a harmonious society, through a platform for cultural exchange of good neighbourly and friendly relations.

When Japanese scholars examine the changes and characteristics of Islamic Studies in Britain, what arouses our interest is not only whether we should adopt the Western and British comprehensive research method of paying attention to the "present tense" of the Islamic world in the context of globalization, but also to deeply explore its practical problems. In order to better serve the Japanese scholars' realistic demands of interpreting the Islamic world, and more importantly, our analysis of the trend of western academic practice, we should understand the nuances and diversity of Western perspectives (the West is not monolithic), and trigger our own in-depth thinking about Islamic culture research. On this basis, we need to further consider the enrichment and improvement of our own academic discourse system. In other words, our academic position should be Japanese; our Academic vision international.

Recently, the study of Islam and the Middle East in Japan has made important progress with the appearance of many young scholars who come from different disciplines and publish their research results in English or other foreign languages. Therefore, the research trend of Japan began to attract the attention of more foreign scholars, and has gotten quite positive evaluation.

This will inevitably lead to differences in research issues and methods between European scholars such as Britain and Japanese scholars, which we have not realized so far. The author has learned a lot from traditional Sinology in Japan and Islamic Studies in Britain and the Middle East. Now we should seriously consider a question: how can we duly make contributions to the study of world Islam and the Middle East.

The author believes that the Islamic research in Britain takes the way from philosophy to history, which has had an important influence on the Islamic and Middle East Studies in Britain and Japan. On the other hand, the UK has a close relationship with the Japanese government's world strategy, and its focus is on the political and economic situation in regions such as China, Southeast Asia and the Middle East. Our regional studies emphasize the historical angle and comparative method, and the purpose is to have a general understanding of the history, society and culture of each region through multidisciplinary research. That is, we intend to combine traditional Islamic research with new regional studies, as well as the introduction of historical perspectives and comparative research methods. These are the research topics and prospects that we have established in the 21 st century.

The study of "academic history" is in a field of special value and significance. It emphasizes that we must make a review and critical reflection on the research history from an academic perspective.

The academic circles in Japanese and British have accumulated many academic achievements in the past few centuries in the study of Islam and Muslim issues, and have established a certain disciplinary system. In the field of Islamic and Muslim issues, Islamic studies with such academic ideas and religious methods have sprung up, opening an unprecedented new research situation. 